\title{
TWO UNRECORDED NOTICES OF WHITMAN IN 1888
}

\author{
JOEL MYeRson
}

Most NOTICES OF Whitman that supplement the standard bibliographies of him by Scott Giantvalley and Donald Kummings have either been contemporary reviews of his works or parodies of his poetry. ${ }^{1}$ The items reprinted below, both published in 1888, are different: one is a favorable poetic statement about Whitman, the other a positive biography of him for young readers.

Writing in Treasure Trove: An Illustrated Magazine, Charlotte French continues for young readers the tradition of "The Good Gray Poet." Concentrating on Whitman's Civil War years (and drawing heavily upon Richard Maurice Bucke's 1883 biography of Whitman), French, like so many anthologists during this time, ${ }^{3}$ deals with a period of his life and his actions (called "patriotic") that struck a positive response with the post-war generation. The issue even contains a reprinting of "As Toilsome I Wander'd Virginia's Woods," which had first appeared in DrumTaps (1865). French is quite fair to Whitman, balancing the negative critics (who said his verses were "bad, nonsensical, and conceited") and the positive ones (who called them "very grand and beautiful"), concluding rather sensibly that whatever Whitman has "written since has only confirmed each side in its own opinion." Nevertheless, French notes that while he "prides himself on being the poet of the common people," the "common people do not understand his poems and never read them." Still, this is in many ways the standard boy-to-man sketch of the juvenile magazines, and a surprising entry for them of someone who was banned in Boston.

In writing "A Parable for Walt Whitman," Coates Kinney presents a rare poetic tribute to his fellow poet. ${ }^{4}$ Kinney (1826-1904), called the "Poet Laureate of Ohio," equates Whitman with Vesuvius and Pompeii, in that, like them, his current "spontaneous gush" will be "preserved ... for ages." Kinney's support of Whitman is not surprising: in an 1856 article on "Poetry and Poets," after quoting Emerson favorably, he defines poetry as "the great, beautiful making of the universe, matter and mind, the more of which we understand within ourselves the more 
are we poets," and notes that "there may be thoughts and language so illustrious as to seem lowered by rhyme."

\section{University of South Carolina}

\section{THE GOOD GRAY POET}

\section{Charlotte French}

"Starting from fish-shape Paumanok where I was born, Well begotten and raised by a perfect mother."

It takes some previous acquaintance with Walt Whitman, to understand that he means he was born on Long Island. Its Indian name was Paumanok, and if you look at the Island on the map you will see that it certainly is "fishshaped." Whitman belongs to a good family, and his mother was a beautiful woman, the idol of her children.

His early home was called West Hills, and his poems are so full of the impressions made on him there, though he was very young when he left it, that a great admirer of his said, "No one can ever really get at Whitman's poems, and their finest lights and shades, until he has visited and familiarized himself with the freshness, scope, wilderness, and sea-beauty of this rugged island." 6

Walt's growth was much like that of other boys, except perhaps that being one of a large family he had to work harder than most boys do. He went through the Brooklyn public school, learned to set up type in a printing-house, taught school himself, wrote for magazines, and newspapers, and finally edited one of the latter, all before he was twenty.

Then he decided to live in New York, or as he expresses it, become a "Dweller in Mannahatta, city of ships, my city."

He says he was "a lover of populous pavements." He enjoyed the crowds, he mingled freely with the very poor, and tried to learn their way of living and thinking, and they loved and trusted him. He would ride back and forth on the ferry-boats for the pleasure of watching the passengers, and he enjoyed above all things a trip down Broadway on top of an omnibus.

He was fond of talking about himself in his poems. In one place he says he was "Fond of Brooklyn, fond of Broadway, fond of the life of the wharves and great ferries." In the same poem he describes his personal appearance:

"Ample-limbed, a good feeder, weight a hundred and eighty pounds; Full-blooded, six feet high, forty inches round the breast and back;

Countenance sunburnt, bearded, calm, unrefined;

Reminder of animals, meeter of savage and gentleman on equal terms; Attitudes lithe and erect, costume free, neck gray and open."

He was indeed a handsome man and grew gray very early in life. He was always scrupulously neat, but even when dressed for company no one could induce him to wear a neck-tie, and his turned-down collar and low-buttoned 
shirt looked strangely out of place among men in ordinary costume.

$\mathrm{He}$ had wonderful keenness of hearing and scent. He even thought he could hear wheat grow and smell the different kinds of snow.

All the time he was working and enjoying himself in his own peculiar way in New York, he was slowly composing the poems he would afterwards publish in the little book called "Leaves of Grass." When he wanted to be entirely alone he would go off to Coney Island, then a desolate, uninhabited spot that nobody else ever visited.

When "Leaves of Grass" was published, people paid little attention to it, until Emerson, always generous, wrote him a letter of praise which he published. Then everybody thought they must read the poems of which the Concord philosopher thought so highly, and soon a perfect storm arose on the subject.

Some critics said they were bad, nonsensical, and conceited, and the newspapers made all manner of fun at them. A few others, and those mostly poets themselves, said they were very grand and beautiful, and that Walt Whitman was the greatest poet in America, perhaps in all the world. Above all things they praised him for being patriotic and original, and this he certainly is.

Whatever he has written since has only confirmed each side in its own opinion. Whether the question will ever be settled or not is doubtful.

He prides himself on being the poet of the common people, but unfortunately the common people do not understand his poems and never read them.

He was devoted to children and they were always ready to go to him. Once when he was invited to meet some prominent people who wished to do honor to the new poet, soon as the introductions were over, he sidled off to a corner of the room where there was a group of young children, with whom he talked and laughed and played, evidently to their mutual satisfaction. "Our company, who had come from a distance to see Mr. Whitman, and did not expect another opportunity, were quite annoyed, and my mother was finally commissioned to get him out of his corner. When she told her errand he looked up with the utmost merriment, and said, 'O, yes, I'll do it, where do you want me to sit? On the piano?' He went forward very good naturedly, however, but I knew that his happy time for the evening was over."7

When he got tired of "Mannahatta," he wandered over the West and South earning money by teaching or writing, when he needed it, and making friends with the working people wherever he went.

He was bitterly opposed to slavery, and wrote poems about the war, but they did not stir the nation as. Lowell's and Whittier's did. In another way, however, he accomplished a noble work for the North.

His brother George was struck in the face by a shell at the first battle of Fredericksburg, and Walt started for the front to nurse the wounded soldier, as soon as he heard the dreadful news. George soon got well, but there were many others who needed his tender and sympathetic nursing, and for three years he remained in the hospitals either at Washington or at the seat of war, devoting himself to the suffering.

"The hurt and the wounded I pacify with soothing hand, I sit by the restless all the dark night, some are so young, 
Some suffer so much-I recall the experience sweet and sad.

Many a soldier's loving arms around this neck have crossed and rested, Many a soldier's kiss dwells on these bearded lips."

He would take no pay for his services, but lived by writing war articles and hospital sketches for New York papers, spending all he could save on his suffering charges. There are many interesting accounts of his life at this time. One writer describes a visit to the hospital with him:

"There were three rows of cots, and each cot bore its man. When he appeared, in passing along, there was a smile of affection and welcome on every face, however wan, and his presence seemed to light up the place as it might be lit by the presence of the Son of Love.

"From cot to cot they called him, often in tremulous tones or in whispers; they embraced him, they touched his hand, they gazed at him. To one he gave a few words of cheer, for another he wrote a letter home, to others he gave an orange, a few comfits, a cigar, a pipe and tobacco, a sheet of paper or a postage stamp, all of which and many other things were in his capacious haversack. From another he would receive a dying message for mother, wife or sweetheart; for another he would promise to go an errand; to another, some special friend, very low, he would give a manly farewell kiss. He did the things for them which no nurse or doctor could do, and he seemed to leave a benediction at every cot as he passed along. The lights had gleamed for hours in the hospital that night before he left it, and as he took his way towards the door, you could hear the voice of many a stricken hero calling, "Walt, Walt, Walt, come again! come again!" 8

As a contrast to this, another writer tells how he lived by himself in those trying days.

"He occupied a little room in the third or fourth story of a house where he could get the cheapest rent. He was just eating his breakfast; it was about ten A. M.; he sat beside the fire, toasting a slice of bread on a jack-knife, with a cup of tea without milk; a little sugar in a brown paper, and butter in some more brown paper. He was using all his means, and time, and energies for the sick and wounded in the hospitals."

At last even his splendid constitution gave way under such a strain, and he had a severe fit of illness. When the war was over he received a government appointment, but was immediately discharged by the Secretary of the Interior, who disapproved of his writings.

He received another appointment, however, which he held until a stroke of paralysis made him incapable of work. He is still living and is said to be very poor, but he is very proud, too, and hates to take help even from his best friends.

\section{A PARABLE FOR WALT WHITMAN}

OLD Vesuvius, calmly possessing its forces primeval,

Keeping them pent in its bosom as far, dim dreams of the passions

Which in its youth it had vented in red molten outbursts of thunder, Held its form and stood serene through ages and ages. 
Men had forgotten its ravages. Villages clustered about it.

Peasantry climbed it with vineyards. The opulence, luxury, pleasure,

Learning of dissolute Italy lolled in the charm of its outskirts.

Spartacus banded his gladiatorial athletes for freedom

Once in the top of it - safe in its great, broad cup, which was empty

Then, long then, of the wine of its wrath, wherewithal it had staggered

When, through its mad young years, in carouse with its comrades Titanic,

Ischia, Barbaro, Somma, Arsoni, and Solfatara. ${ }^{10}$

Mediterranean winds blew balm through its orchards and gardens.

West, and north, and east it swung, from sunrise to sunset,

Slowly about from its shoulders its long, wide mantle of shadow,

Shielding the men at their toil on the slopes and the birds at their singing.

Far to the folk coming in on the ships it appeared a great pillar,

Steadfast prop of blue roof of sky over blue floor of water,

While, aland, it showed itself bulked on the world's gravitation,

Fixed of form and poised serene through ages and ages.

Suddenly then, with a bellowing frenzy, it panted out darkness

Over itself and the land and the sea; as a priest gone apostate,

Tore off its mitre and hurled it (renouncing the faith with blaspheming)

Down on the worshippers; growing in rage, drew a dagger of lightning,

Brandished, and slashed all its veins and bled hell-fire. And the people,

Seeing sublimity gloom into horror, and day into midnight-

Majesty topple from cosmical forms into rubbishy ruin-

Rocks fly as meteors, chaos ejaculate flame, and with thunder

Sputter plutonian ashes and scoriac cinders-the people

Fled from the mountain, abandoning castle, and farmhouse, and villa,

Stumbling their perilous ways through the roar, and the stench, and the blackness

Out to the sun on the plain of Campania. Multitudes perished,

Whelmed by the fire-flakes that fell from the clouds of the smoke like a snowing.

Civilization forgot them for centuries. Stricken Pompeii,

Borne down under the deluge infernal, and smothered and buried,

Sank out of memory, lost, and no more was it known where its grave was.

Now, after hundreds and hundreds of years, is unearthed the dead city.

Matter that once flew as flame in the heavens and startled an empire,

Dig it up, shovel it, cart it away, it is dirt and obstruction,

Hiding the relics of man and the rare forms of art he has fashioned.

Here in the marl is the mold of an old Roman sentinel's body,

Now more than eighteen centuries dead at the post of his duty.

Here is the exquisite ring of a bride whose love is immortal.

Here is the beautiful dwelling of Sallust. Here theatre, forum,

Where Rome's language, whose ghost, from the Church, still haunteth the nations,

Lived on the stage and the rostrum - in greeting of neighbor to neighbor-

Shouted the plays of the school children here in the streets. And the temples,

Here they stand in the full broad day of the worship of Jesus,

Shockingly waked from their obsolete gods as from dreams in a nightmare.

What the spontaneous gush from yon old and familiar volcano,

Violent, formless, beside these reminders of man and his labors?

Yet the volcano had covered all these and preserved them for ages.

Coates KInNeY 


\section{NOTES}

1 See Scott Giantvalley, Walt Whitman, 1838-1939: A Reference Guide (Boston: G. K. Hall, 1981), and Donald D. Kummings, Walt Whitman, 1940-1975: A Reference Guide (Boston: G. K. Hall, 1982).

2 French, "The Good Gray Poet," Treasure Trove: An Illustrated Magazine 11 (May 1888), 282-283; “As Toilsome I Wander'd Virginia's Woods" appears on 275. I have silently corrected typographical and spelling errors in both items.

3 See Ed Folsom, “Affording the Rising Generation an Adequate Notion': Walt Whitman in Nineteenth-Century Textbooks, Handbooks, and Anthologies," Studies in the American Renaissance 1991, ed. Joel Myerson (Charlottesville: University Press of Virginia, 1991), 345-374, for an extended discussion of why Whitman's Civil War verse was so attractive to anthologists and critics.

4 Kinney, “A Parable for Walt Whitman," Belford's Magazine, 1 (August 1888), 372-373.

5 Kinney, “Poetry and Poets," Ladies' Repository, 16 (March 1856), 170-174.

6 William Douglas O'Connor, quoted in Richard Maurice Bucke, Walt Whitman (Philadelphia: David McKay, 1883), 18.

7 Helen M. Price, quoted in Bucke, 97.

8 John Swinton (quoted from the April 1, 1876, New York Herald) in Bucke, 36.

9 Quoted from a letter "by a lady addressed to the present writer" in Bucke, 38.

10 Mountains, cities, or geographical areas near Pompeii. 